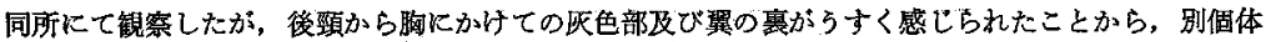
の可能性むある.

この種の和名は,「世界の鳥の和名」(山階鳥類研究所 1980) によればクロハシンリカモメとなって いるが, 著者らの観察した印象からは，七メュリカモメが適当と思われた．な和，本種は北米大陸の アラスカ・カナダで繁殖し，冬期は南方へ移動し，メキシコまで渡るまた，ハワイやイギリスでの 記錄がある (HARRISON 1983).

引用文南. Grant, P. J., 1982. Gulls: a guide to identification. Calton, P \& A D Poyser. - Harrison, P., 1983. Seabirds. Beckenham, Croom Heim. - National Grographic Society, 1983. Field guide to the birds of North America. Washington, DC, National Geographic Society. - 山階鳥類研究所 (編), 1980. 世界の鳥の和名: 北アメリカの鳥. 東京, 山階鳥類研究所.

The First Record of the Bonaparte's Gull in Japan. The authors observed and photographed a 1st winter Bonaparte's Gull Larus philadelphia at Nakaminato City, Ibaragi Pref. on 14 December 1985. It was seen with flocks of Black-headed Gulls Larus ridibundus. This is the first record of the species in Japan.- - Mitsuo Imal, Shigeo Ozawa and Tadao ShrnBa.

First author's address: Takaisodai Apartment B-404, Ogitsu-cho 3679, Hitachi-shi, Ibaraki 31914. 荻城県日立市小木津町 3679 高硨台アパート B-404.

Jap. J. Ornithol. 35: 34-35, 1986

\title{
An Invasion of Egrets and Herons in Eastern Hokkaido
}

\author{
Mark BRAZIL
}

Nineteen species of Ardeidae have been or are regularly recorded from Japan, four of these occur regularly in Hokkaido (WBSJ 1982), but only the Grey Heron Ardea cinerea can be regarded as common there. Other species occur only as uncommon migrants or as vagrants, with their frequency of occurrence being poorly known. IIJMA (1984), however, reported records of several species of 'white' egrets in south central Hokkaido over a ten year period up to and including 1983 and suggested that the numbers of the Cattle Egret Bubulcus ibis in particular are on the increase.

During a two-and-a half year period of residence in Hokkaido from spring 1983 onwards, and during numerous visits there, $I$ have been able to observe species other than the Grey Heron on several occasions. These records invariably involved single birds overshooting on spring migration, since nearly all records were in May and June. InMA's (1984) records, although ranging from April to November, were also concentrated in the spring and early summer and were no doubt a result of the same phenomenon. My own records involved a variety of species: Little Egretta garzetta, Intermediate E. intermedia, Great E. alba and Cattle egrets Bubulcus ibis, all of which breed further south in Japan. On one occasion I was able to observe a Swinhoe's Egret $E$. eulophotes, an extremely rare bird in Japan, which has recently attempted to breed in Honshu, and in association with the arrival of these birds, single individual Eastern White Stork Ciconia ciconia boyciana and Spoonbill Platalea leucorodia were also seen. Late spring and early summer 1986 saw an unprecedented number of egrets and herons reaching eastern Hokkaido totalling more than I had previously seen (Table 1).

These records involve five species and probably at least 13 different individuals just in the small region of Nemuro and Kushiro provinces from Lake Furen to Akkeshi. In addtition to 
Table 1. Sight records of herons and egrets in Nemuro and Kushiro provinces in 1986.

\begin{tabular}{llcl}
\hline \multicolumn{1}{c}{ Species } & \multicolumn{1}{c}{ Sate } & No. & \multicolumn{1}{c}{ Locality } \\
\hline Nycticorax nycticorax & May 31 & 1 & Bettoga River $^{1}$ \\
Bubulcus ibis & June 9 & 11 & Bettoga River $^{1}$ \\
& May 12 & 1 & Maruyama Chirippu $^{2}$ \\
& May 27-29 & 2 & Yarimukashi \\
& May 27-31 & 2 & Bettoga River \\
& May 30-31 & $2-3$ & Yarimukashi \\
& June 1-3 & 2 & Yarimukashi \\
& June 6-7 & 2 & Bettoga River \\
Jgretta alba & June 9 & 2 & Bettoga River \\
Egretta intermedia & May 12 & 3 & Yarimukashi \\
& May 29-June 3 & 1 & Yarimukashi \\
\multirow{2}{*}{ Egretta garzetta } & June 6 & 1 & Yarimukashi \\
& June 9 & 1 & Hashirikotan \\
& May 29-31 & 3 & Yarimukashi \\
& June 1-3 & 2 & Yarimukashi \\
& June 6 & 1 & Yarimukashi \\
\hline
\end{tabular}

${ }^{1}$ Nemuro Prov.; ${ }^{2}$ Kushiro Prov.

these records, single individual Purple Heron Ardea pururea (which in Japan breeds no closer than Iriomote in the extreme southwest Ryukyu Islands), and Swinhoe's Egret, were recorded in the Nemuro Peninsula-Lake Furen area during the same period (M. TAKADA pers. comm). A single Swinhoe's Egret has appeared annually in recent years at Lake Furen in early summer (M. TAKADA pers. comm.). The appearance of seven species of heron and egret in eastern Hokkaido suggests that a relatively large invasion took place. This invasion may in fact have been more widespread and records from other parts of Hokkaido may come to light.

It is of particular interest that despite the vast size of the marsh and reed bed at Yarimukashi the egrets there (up to 5 or 6 individuals) spent much of their time in the immediate vicinity of the nest of a pair of Japanese Cranes Grus japonensis. Not only did the egrets feed and roost nearby, but on several occasions they were observed standing around, and even on, the base of the nest mound itself. The female crane was quite distracted by their presence, occasionally lunging at them to displace them. 'White' egrets are gregarious, regularly occuring in flocks, and also nesting in colonies. The presence of this huge white bird in the marsh seemed an irresistable attraction and acted as a nucleus for flock formation. In winter it is not uncommon for other species of cranes to be attracted to the wintering flocks of Japanese Cranes near Kushiro (for example a White-naped Crane G. vipio was present with one flock at Tancho no Sato in winter 1981-1982, and at least one Common Crane G. grus joined Japanese Cranes in winter 1985-1986 at Tsurui). This is, however, the first time that $I$ have noticed an attraction to cranes during the breeding season, and the first time I have observed egrets attracted to cranes.

Literature Cited. IIJMA, Y., 1984. Sight records of Bubulcus ibis, Egretta alba, E. intermeiia and E. garzetta in Taiki, Hokkaido. Tori 33: 44-56. - WBSJ (WILD BIRD SocIETY OF JAPAN), 1982. A field guide to the birds of Japan. Tokyo, WBSJ.

北海道東南部におけるサギ類の鹳塞. 北海道では, アオサギを除いて，サギ類の記録㹥最近まで非 常に少なかった. しかし, IIJMA (1984) は十勝大樹町で数種のサギ類を観察し, とくにアマサギの增 加について述べた. 筆者も，1986 年の 5-6 月に, 根室および釧路支宁管内で 5 種のサギ類を観察した. これらはいずれも 1 羽ないし数羽で観察され, 観察時期も5-6月に集中しているので, 春の渡りのす のが北海道にまで北上したと考党られる.—-Mark BRAZIL.

Author's address: Asakawa Kopo Apt 205, Hyakunin-cho 1-3-24, Shinjuku-ku, Tokyo 160. 東京都新宿区百人町 1-3-24 アサカワコーポ 205 昼. 